\title{
Internet Banking Acceptance: A Comparative Study between the Kingdom of Saudi Arabia and the USA
}

\author{
Shaza W. Ezzi \\ King Abdulaziz University, Jeddah, Saudi Arabia \\ Shazaezzi466@gmail.com
}

\begin{abstract}
Internet banking, as with various types of electronic commerce, has grown from consumers' needs to have greater access to banking services beyond the normal operating hours of teller-staffed banks. Also, new applications such as mobile devices used for Internet banking have provided the impetus to meet rapidly growing and sustained increases in retail e-commerce. Internet banking (IB) has been well-researched from the perspectives of perceived ease of use (PEOU) and perceived usefulness (PU) as indicants that positively affect adoption. Using the Consumer Internet Banking Model (CIBM) the goal in the present study was to investigate IB adoption based on the effects of three additional factors: perceived privacy, perceived Web security, and trust. The CIBM is a theoretical model designed to help researchers and practitioners to better understand the acceptance and adoption of Internet Banking. The initial findings of the present study suggest that Saudi Arabian respondents differ significantly from their USA/American counterparts with respect to security, privacy, and trust with respect to adoption of Internet banking, and intentions to use Internet banking. The final section of the paper presents future research avenues and concluding remarks of the findings.
\end{abstract}

Keywords: Internet banking, Perceived Privacy and Perceived Web Security, Trust, Saudi Arabia, USA

\section{INTRODUCTION}

The driving force behind the growth in Internet banking (IB) may be traced to two phenomena: the unprecedented rate of growth in e-commerce, and customers' needs to have greater access to banking during non-operating hours [1-3]. In addition to completing purchase transactions, banks rely on their customers to use their electronic facilities to perform other banking services. Some of the other services IB provides to bank customers would be paying bills electronically, transferring funds between accounts, and conducting personal financial planning [4-5]. There are, however, some differences in the marketing goals of retailers and banking institutions. For example, there is a subtle yet key difference in customer approach between e-commerce (retailer) sites and Internet banking sites. E-commerce retailers may know something about customers from previous sales transactions and memberships but many potential customers are entirely new visitors whom may never have transacted with the company. Alternatively, banks that host Internet banking portals know in advance all of their potential customers at any given moment, and do not promote opportunities to affect spontaneous financial transactions in at-large markets or channels. The security reasons for this are many, but the most essential is that, unlike e-commerce retailers, banks that offer Internet banking still require new bank as well as most existing customers to personally visit 
teller-operated locations to sign paperwork (that in few instances may be accomplished via poste) that establishes the legal and fiduciary financial relationships between bank and customer [6]. Once becoming customers, account holders receive coded information that allows them access to technology enabling the completion of a host of banking transactions easily and conveniently from their homes or offices using a PC and the Internet. However, the rapid growth in information technology has also ushered in many consumer risks concerning bank customer information privacy and security of conducting Internet banking transactions [e.g. 7; $1 ; 8-9$ ]. For example, JP Morgan Chase and Co was affected by a cybersecurity attack in August of 2014 that allegedly involved the records of 76 million USA households. And, while the hackers were not able to retrieve actual account information i.e. passwords, account numbers, and the like, these cyber criminals could access customers through their email accounts and try to entice them with assortments of nefarious financial schemes [10]. Thus, perceived privacy and security, and trust have become vital factors which may contribute to the relative propensity of customers to adopt, use and increase their frequency of IB services. Based on the Consumer Internet Banking Model (CIBM) - (see figure 1) [11], the purpose of the current research is to investigate the effects of these factors on customers' intentions to adopt and use IB services.

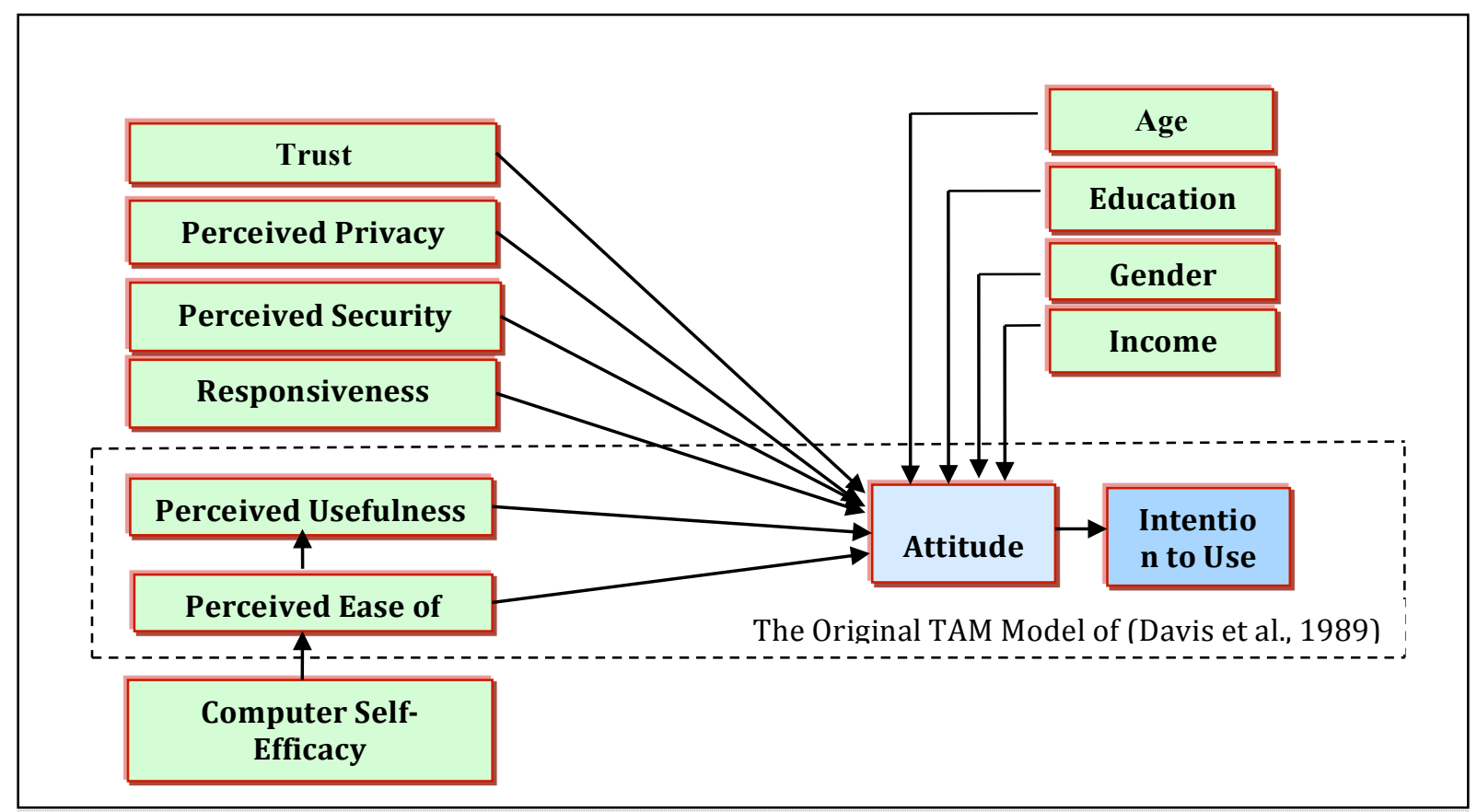

Figure 1: Consumer Internet Banking Model (CIBM), Ezzi (2014)

\section{LITERATURE REVIEW}

Internet technology has influenced the everyday life of millions of individuals worldwide for the last two decades because of the potential to affect and enhance consumers' desires to shop and complete purchase and non-business transactions outside of ordinary channels [e.g. 1213] Within the academic literature, electronic banking is an umbrella concept defined by distant, real-time access to banking services using a variety of means such as Internet banking portals, on-line banking, PC banking, including the use of ATM's [14]. PC banking, a precursor to Internet banking, describes banking between a personal computer user and an internal banking network. Internet banking (IB), as used in this paper, is a true synonym of on-line banking, and describes distant banking conducted using a PC and an Internet-based browser. IB supports the mission of banks to increase services and build customer satisfaction through providing virtual time products and services, with the potential to realize reduced operating 
and administrative costs [12; 15-17]. Today, in the developed countries of North and South America, Europe, Australia, and many parts of Asia individuals can transact consumer-banking needs using personal computers. Further, IB has expanded to include mobile devices like Smart phones and hand-held tablet computers [18-19].

Further, the advent of Internet banking (IB) technology has improved the ease and accuracy of making and completing purchase transactions through a wide range of e-commerce web sites [1]. Prior research has shown a strong positive connection between consumers' perceived ease of uses (PEOU) and perceived usefulness (PU) and the adoption and use of IB by bank customers [e.g. 16; 20]. Intuitively, these findings seem to make sense from a technology perspective. The easier it is for consumers' to grasp new technological changes in their environment and the more useful the outcomes are, the more likely they will be to continue to embrace the new technology $[21-22 ; 7 ; 23 ; 18 ; 17]$.

Compared with brick-and-mortar branch banking, customers using IB services are subject to different security, privacy and trust issues which may stem from the need to use technology for processing transactions, the impersonal and distant nature of conducting business on-line, and the potential uncertainty of completing transactions in an open environment [24-25]. For many customers the temporal and spatial factors which separate face-to-face banking from Internet banking create issues of security, privacy and trust, and have become impediments to the adoption of IB [26-28; 19].

Privacy and Security Risks: The main problems for banks and their Internet users stem from issues that present challenges of maintaining customers' privacy and securing their bank transactions [29; 20]. Interestingly, most of the threats associated with transacting business and social media on-line, which affect users from a variety of Internet sources, are widespread and may affect Internet banking users as well. Some of the best known Internet security breaches stem from various forms of viruses, e.g. Trojan horse, and pirate applications such as malware and spyware, and illegal data collections from sources like phishing [e.g. 30-31]. For example, a Trojan horse virus, derived from the story of the wooden horse gifted by Greeks used to trick the defenders of Troy, is a generally non-self-replicating type of malware program that affects the host computer [e.g. 32; 8]. The Trojan type of virus usually contains a malicious code that, when executed, carries out actions typically causing loss or theft of data and personal information, and possible system-wide file damage. Trojan viruses generally use social engineering to mimic legitimate programs by presenting the appearance of routine and useful information designed to convince victims into installing them on their computers. Trojan viruses have been used to hack files and steal personal financial information from unsuspecting users of IB and other financial services [32]. Phishing, an example of social media engineering gone awry, is a cyber-con designed to deceive on-line users by having them voluntarily enter personal financial information to fake websites that masquerade as legitimate ones [32; 8; 30]. Email communications are generated by bogus companies designed to look like banks, retail sites, Internet payment service providers, and the like. Many Internet security risks are based on deception and exploiting the usability of current web security technologies [8; 30]. Managing security and privacy risks are of paramount importance to banks seeking to establish trust among prospective IB users. McKnight, Choudhury, and Kacmar [26] suggest that the content and quality of the service providers' websites can do much to reduce IB customers' perceived security and privacy risks.

Trust: Rousseau, Sitkin, Burt, and Camerer [33] conducting a meta-analysis identified two factors implicit to most organizationally-based trust research. These factors are: (1) the element of perceived risk on behalf of the subscriber who is vulnerable in the transaction to 
the service provider, and (2) that the service provider will operate in the best interests of the subscriber. McKnight and Chervany [34, p. 29] suggest that "Trust is important to organizations because it lubricates the relationships that form the interlocking components of coordination, which, like gears, turn the wheels of commerce." Based on their review of selected e-commerce studies, Yousafzai, Pallister, and Foxall [24, p. 850] define Internet banking customers' trust as "a psychological state which leads to the willingness of customers to perform banking transactions on the Internet, expecting that the bank will fulfill its obligations, irrespective of customer's ability to monitor or control the bank's actions."

McKnight and Chervany [34] suggest that customers have several methods of "neutralising" any negative effects relating to security, privacy and inherently building greater trust among IB users. Without suggesting it is as such, these researchers and several others [e.g. 35; 16; et al] advocate for customers to avail themselves of both inside and outside information to address security and trust issues. For example, the banks reputation in the community and number of branch offices may provide outside signals of institutional strength and reliability. On the other hand, on-line security agreements that address responsibility for fraudulent or mistaken transactions sends an inside message to customers regarding the banks reliability and trustworthiness. Another inside signal that may allay customers' security and privacy fears are well-maintained, professional-appearing websites that show the bank or financial institution's positive commitment to Internet banking. Research has shown a connection between the dimensions of web site design, reliability, and trust and overall service quality and customer satisfaction. For example, Wagner and Rydstrom [22] in a study of US Internet shoppers found that Internet-user satisfaction and trust are increased when consumers feel that the firm has invested in sufficient resources to fulfill information needs and successfully complete transactions. Further, trust has been found to have a significant effect on customers' attitudes toward Internet banking [35-36]. Also, research from retailing and banking suggests that to enhance customer purchase/use intentions, online stores/banks should develop marketing strategies to better address IB user's perceived reliability, privacy, responsiveness, and trustworthiness of web-based services [37-39; 16]. Decreasing security and privacy concerns while increasing customer trust could lead to greater IB adoption. This could lead to increased customer satisfaction and loyalty, and build lasting banking relationships. Additionally, firms that successfully incorporate IB into their service palettes may realise organizational goals of reduced services costs and more efficient banking operations [40; 16]. Thus, to ameliorate customers' perceived risk and trust concerns and perhaps be more profitable it is essential that banks offering Internet banking services use marketing to enhance their customer reputations and devote significant corporate resources in developing their websites. Investigating the ways that the variables perceived privacy and security and trust affect adoption and intent to use Internet Banking is a prime goal of the current research.

\section{RESEARCH OBJECTIVES AND QUESTIONS}

Consumers are increasingly drawn to using the Internet as a consumption channel for satisfying their transactional needs and wants. In that regard, it is incumbent upon managers of the financial services industry to understand consumers' Internet banking needs, and to develop products and services designed to meet these needs. This will require bank managers to develop "know-how" with respect to attracting Internet banking (IB) users to drive transactions sales and profits. As the various distribution and marketing channels continue to grow and with a particular focus on increased online capability perceived security and privacy risk concerns can become an impediment to the adoption and usage of Internet banking [26$27 ; 41]$. 
The main research objectives of this study are to present findings to better understand if and/ or how customers in two culturally diverse countries differ in their respective perceptions of Internet security and the risks associated with on-line transactions; the privacy of their accounts and transactions information; their level of trust in the banks sponsoring IB, and their attitudes toward the adoption and usage of Internet banking services, overall.

One of the countries in this comparative study Saudi Arabia (SA) is characterized by a growing and developing economy one that historically has been centered on the development of petroleum and related industries. However, modern-day Saudi Arabia is a country with rival state-of-the-art infrastructure necessary to support advanced levels of business, including online commerce. The geographical locations of the country's main three commercial hubs that stretch from the oil-rich lands of Dhahran in the east to the capital city Riyadh in the center spanning to Jeddah in the west along the Red Sea are separated by vast undeveloped areas. This sort of geography favors the development of commerce able to span the vast areas and is particularly well-suited for the development and adoption of electronic commerce applications like Internet banking. And, from a consumer point of view, customer banking that could be accomplished via the Internet means customers could avoid significant wait times to interface with tellers, which is commonplace among SA banks. However, strict social mores often determine the interaction between the modern secular world and the holy Islamic world. The second country in the study is the United States of America (USA) with a long history as being a highly developed country with a highly diversified economy. The USA with a well-established Internet banking sector is also a culture with far more liberal social attitudes. The findings from the comparisons of these two diverse countries could provide useful information for bank managers whose task it is to formulate IB marketing strategies to increase IB adoption/usage in the future. In addition, the research findings of potential factors influencing Internet Banking usage in Saudi Arabia may provide useful insights for other countries with similar developing economies.

Research questions 1 - 5: Researchers in prior studies have found differences related to attitudes toward and adoption of Internet usage based on demographic differences, particularly with respect to nationality and country of origin. For example, with respect to the variable trust, large German banks enjoy solid brand reputations built over time and through the trust that people have historically placed in them [42]. Another reason underlying high level of trust is that the German banking sector is heavily regulated, more so than even the U.S. Thus, the quality and quantity of information on the IB product offerings that impact trust would be more important for consumers in the U.S. than for those in Germany [42]. Interestingly, with respect to consumers trusting websites, Cyr [43] found that loyalty was important to Germans and Chinese, but not so with Canadians. In a similar study Kim, Donald, and Rao, [44] found loyalty was important to American website consumers. More recently in a study of Saudi Arabians, Eid [23] found as perceived security and privacy risks decreased that trust increased. These findings lend further support as the constructs of perceived security and privacy risk were found to be positively related to increased trust and also customer satisfaction in several earlier studies involving other nationalities such as US consumers [22] and South Korean consumers [7]. In a 2006 study on Spanish consumers Flavián and Guinalíu [41] found that an individuals' website loyalty is closely related to their levels of trust in the organization. Thus, the development of trust between Internet users and website sponsors not only affects the consumers intention to adopt and use the services, as shown by some earlier research, but may also affect the frequency of visits, and potentially the level of profitability of each consumer. Additionally, as with several other researchers, Flavián and Guinalíu [41] analyses suggest that trust in the Internet is related to the level of perceived security by consumers regarding the handling of their private data. 
Based on discussions above and the findings of prior researchers [e.g. 22; 7; 41; 43-44; 23] between group analyses of Saudi Arabia (SA) and the United States of America (USA) will show significant differences with respect to perceived web security, perceived privacy, trust, attitude toward, and the adoption of Internet banking. Some researchers investigating convenience, related to perceived ease of use (PEOU), have found this element to be related to users' intentions to adopt Internet banking [45-46;3]. Thus, from a practical standpoint, the element of convenience that IB services provide to all consumers suggests there should be no significant difference between SA and USA respondent's intentions to use Internet banking services.

Research question 1: There will be a significant difference on the measurement of perceived web security between SA and USA respondents.

Research question 2: There will be a significant difference with how respondents from SA and USA value privacy of Internet banking information and transactions.

Research question 3: There will be a significant difference on the measurement of trust concerning Internet banking between SA and USA respondents.

Research question 4: There will be a significant difference on how SA and USA respondents respond to attitude toward adoption of Internet banking.

Research question 5: There will not be a significant difference on the measurement between SA and USA respondents' intention to use Internet banking.

\section{RESEARCH METHODOLOGY}

Data was gathered using a survey questionnaire based on the research construct items: perceived security (risk); perceived privacy; trust; attitude toward Internet banking; and intention to adopt and use Internet banking. The survey items were rated on a five point Likert scale instrument where; 1 = 'Strongly Disagree'; 2 = 'Disagree'; 3 = 'Neither agree nor disagree'; 4 = 'Agree'; and 5 = 'Strongly Disagree.' The surveys administered in Saudi Arabia were written in Arabic, and those in the United States of America were written in English.

To examine participant's responses the research constructs in the study were operationalized using existing measures developed and used in prior research (see Appendix 1). Using four items, the perceived web security construct was adopted from Salisbury, Pearson, Pearson and Miller [37] and Cheng, Lam and Young [39].

The perceived privacy construct used three items which were adopted from Ahangar [47]. The three trust construct items were adopted from using three items were adopted from Al-Somali, Gholami, and Clegg [16]. The attitude toward Internet banking construct used six items: three of the items were adopted from Al-Somali, Gholami, and Clegg [16], and the other three items were adopted from Lee [48]. For the construct intention to adopt and use Internet banking three items were adopted from prior research of Al-Somali, Gholami, and Clegg [16]. Demographic characteristics collected on the questionnaires from the sample were: gender, age, occupation and educational level, usage frequency of Internet, Internet banking user. The descriptive statistics are listed in Tables 1-3 under the discussion of the sample. A copy of the questionnaire will be furnished to the reader upon request. 


\section{Sample}

A convenience type sampling procedure was used to collect data for the study. All study participants were bank customers selected from universities, companies and malls. In Saudi Arabia a total of 400 questionnaires were distributed in using the pick-up/drop-off technique in addition to online survey. Excluding missing and incomplete questionnaires, 173 valid responses were collected, for a response rate of $43 \%$. The data of the USA sample was collected through online survey using a convenience sample from four different states - Florida, Michigan, Georgia and California. The survey was conducted through contact persons from several universities in these states. After 30 days, a total of 125 usable questionnaires were collected. The samples collected above are subject to biases because the researchers may have unconsciously approached some kinds of respondents and avoided others [49], and respondents who volunteer for a study may differ in unknown but important ways from others [50]. The rationale for using these methods was expediency and cost, and due to the exploratory nature of the study. An important consideration was the issue of sufficiency in the number of observations to meet the purposes of the study, measuring consumer attitudes. According to completed studies that investigated similar attitude phenomena there should be at least 103 observations [52-54]. Thus, sample sizes of 173 and 125, respectively were considered sufficient for the purposes of the study.

\section{DATA ANALYSIS}

Five research questions that were generated above are the basis for the analysis in the study. Descriptive statistics, Pearson correlations, some independent groups t-test analyses were conducted on the data. Where appropriate, frequency distributions were calculated to show how the variables of interest related to certain research questions.

\section{DESCRIPTIVE STATISTICS}

The descriptive statistics are presented in Tables 1-3, below. Table 1 illustrates the distribution of respondents in the two samples SA and USA by age and gender. Among the 173 of SA respondents 102 (59\%) were male and 71 female (41\%). The largest percentage (63\%) of respondents by age group were Less than/= 30 years old followed by $(32.4 \%)$ of the age group $31-50$ years.

Table 1: Summary Statistics by Age and Gender

\begin{tabular}{|c|c|c|c|c|c|c|c|c|c|}
\hline \multirow[t]{3}{*}{ Measure } & \multirow[t]{3}{*}{ Item } & \multicolumn{4}{|c|}{ SA Sample } & \multicolumn{4}{|c|}{ USA Sample } \\
\hline & & \multicolumn{3}{|c|}{ Frequency } & \multirow[b]{2}{*}{$\%$} & \multicolumn{3}{|c|}{ Frequency } & \multirow[b]{2}{*}{$\%$} \\
\hline & & Male & Female & Total & & Male & Female & Total & \\
\hline \multirow[t]{3}{*}{ Age } & Less than $/=30$ years & 58 & 51 & 109 & 63 & 9 & 9 & 18 & 14.4 \\
\hline & $31-50$ years & 38 & 18 & 56 & 32.4 & 12 & 29 & 41 & 32.8 \\
\hline & 51 years and above & 6 & 2 & 8 & 4.6 & 37 & 29 & 66 & 52.8 \\
\hline \multicolumn{2}{|l|}{ Totals } & $\begin{array}{c}102 \\
59 \%\end{array}$ & $\begin{array}{c}71 \\
41 \%\end{array}$ & $\begin{array}{c}173 \\
100 \%\end{array}$ & $100 \%$ & $\begin{array}{c}58 \\
46.4 \%\end{array}$ & $\begin{array}{c}67 \\
53.6 \%\end{array}$ & $\begin{array}{c}125 \\
100 \%\end{array}$ & $100 \%$ \\
\hline
\end{tabular}

For the USA sample, Table 1 shows that of 125 respondents 58 (46.4\%) were male and 67 $(53.6 \%)$ were female. By age group, the largest percentage (52.8\%) of respondents were 51 and above years old followed by the age group from $31-50$ years (32.8\%), and Less than/= 30 years (14.4\%), respectively.

Chi-squares analyses showed statistically significant differences between the samples for SA and USA with respect to Age and Gender. The World Factbook showed that neither of the samples represented the most recent demographic population profiles for SA and USA in terms of age and gender brackets reported [55]. 
Table 2 presents the distribution of the SA and USA samples by Education and Occupation. Baccalaureate degrees accounted the highest percentage for both samples, $46.8 \%$, for SA respondents and 53.6\%, for the USA respondents. The SA Postgraduate respondents represented $33 \%$ and the USA respondents represented $39.2 \%$. In terms of the occupation distribution, most of the respondents in the two samples were working in private sector $42.5 \%$ for SA respondents and $31.2 \%$ for the USA respondents, followed by Employee in Public sector $29.3 \%$ and $28.8 \%$ for the SA and USA, respectively.

Table 2: Summary Statistics for Education and Occupation

\begin{tabular}{|l|l|cc|cc|}
\hline \multirow{1}{*}{ Measure } & \multicolumn{1}{|c|}{ Item } & \multicolumn{2}{c|}{$\begin{array}{c}\text { SA Sample } \\
\text { (Total 173) }\end{array}$} & \multicolumn{2}{c|}{$\begin{array}{c}\text { USA Sample } \\
\text { (Total 125) }\end{array}$} \\
\cline { 3 - 6 } & & Frequency $\%$ & Frequency & $\%$ \\
\hline Education & High school/ Technical Diploma & 35 & 20.1 & 9 & 7.2 \\
& College degree (Baccalaureate) & 81 & 46.6 & 67 & 53.6 \\
& Post Graduate & 57 & 32.8 & 49 & 39.2 \\
\hline Occupation & Businessman (Businesswoman) & 4 & 2.3 & 22 & 17.6 \\
& Employee in Public sector & 51 & 29.3 & 36 & 28.8 \\
& Employee in private sector & 74 & 42.5 & 39 & 31.2 \\
& Student & 40 & 23.0 & 12 & 9.6 \\
& Retired & 4 & 2.3 & 16 & 12.8 \\
\hline
\end{tabular}

Table 3 shows the Internet and Internet banking service usage history and frequency distributions of the SA and USA samples. The percentages from both samples show that the greatest percentages of respondents indicate they are using Internet from 1 - 10 hours a week; SA $67 / 173=39 \%$, and USA $42 / 125=34 \%$. Similarly, large percentages from both samples indicate high use of Internet banking services, (88 males +58 females $=146 / 173)$ 84.4\% SA and $(49$ males +61 females $=110 / 125)$ 88\% for USA. Not surprisingly, Chi-squares analyses revealed that Internet usage was significantly related to using IB services for both samples: SA $\chi 2(1)=22.43, \mathrm{p}<0.01 ;$ and USA $\chi 2(1)=24.86, \mathrm{p}<0.01$.

Table 3: Internet and Internet Banking Service Usage History and Frequency Distribution (SA \& USA)

\begin{tabular}{|c|c|c|c|c|c|c|c|c|c|c|c|c|c|c|}
\hline \multirow[b]{3}{*}{ Gender } & & & \multicolumn{12}{|c|}{ Number of hours using Internet weekly } \\
\hline & \multirow{2}{*}{\multicolumn{2}{|c|}{$\begin{array}{c}\text { Internet } \\
\text { Banking } \\
\text { Usage }\end{array}$}} & \multicolumn{5}{|c|}{ SA Sample } & \multirow[b]{2}{*}{ Total } & \multicolumn{5}{|c|}{ USA Sample } & \multirow[b]{2}{*}{ Total } \\
\hline & & & $\begin{array}{l}1-10 \\
\text { hours }\end{array}$ & $\begin{array}{l}11-20 \\
\text { hours }\end{array}$ & $\begin{array}{l}21-30 \\
\text { hours }\end{array}$ & $\begin{array}{l}31-40 \\
\text { hours }\end{array}$ & $\begin{array}{c}\text { More } \\
\text { than } 40 \\
\text { hours }\end{array}$ & & $\begin{array}{c}1-10 \\
\text { hours }\end{array}$ & $\begin{array}{l}11-20 \\
\text { hours }\end{array}$ & $\begin{array}{l}21-30 \\
\text { hours }\end{array}$ & $\begin{array}{l}31-40 \\
\text { hours }\end{array}$ & $\begin{array}{l}\text { More } \\
\text { than } 40 \\
\text { hours }\end{array}$ & \\
\hline \multirow[t]{3}{*}{ Male } & \multirow{3}{*}{$\begin{array}{c}\text { Using } \\
\text { Internet } \\
\text { Banking }\end{array}$} & Yes & 39 & 16 & 11 & 9 & 13 & 88 & 21 & 6 & 12 & 3 & 7 & 49 \\
\hline & & No & 5 & 2 & 5 & 1 & 1 & 14 & 3 & 6 & 0 & 0 & 0 & 9 \\
\hline & & Total & 44 & 18 & 16 & 10 & 14 & 102 & 24 & 12 & 12 & 3 & 7 & 58 \\
\hline \multirow[t]{3}{*}{ Female } & \multirow{3}{*}{$\begin{array}{c}\text { Using } \\
\text { Internet } \\
\text { Banking }\end{array}$} & Yes & 28 & 9 & 8 & 3 & 10 & 58 & 21 & 9 & 20 & 11 & 0 & 61 \\
\hline & & No & 7 & 5 & 1 & 0 & 0 & 13 & 6 & 0 & 0 & 0 & 0 & 6 \\
\hline & & Total & 35 & 14 & 9 & 3 & 10 & 71 & 27 & 9 & 20 & 11 & 0 & 67 \\
\hline
\end{tabular}

\section{Correlations}

The Pearson correlation coefficients which represent the strength of the relationships between the study variables are shown in Table 4. It may be observed from Table 4 that the correlation coefficients of the relationships between the study's variables were found significant, as all correlations are over the 0.01 level. In both samples the dependent variable attitude toward Internet banking (ATT) was considerable and positively related to the three dependent 
variables: SA - perceived privacy (PRIV) $r=.400, p=.001$; perceived [Web] security (SEC) $r=.532$, $\mathrm{p}=.001$; and trust (TR) $\mathrm{r}=.313, \mathrm{p}=.001$; and USA - perceived privacy PRIV $\mathrm{r}=.433, \mathrm{p}=.001$; perceived risk SEC $r=.554, p=.001$; and trust TR $r=.491, p=.001$. Additionally, with respect to the dependent variable intention to use Internet banking (ITU) both samples showed significant and positively relationships with the three dependent variables: SA perceived privacy (PRIV) $r=.358, p=.001$; perceived [Web] security (SEC) $r=.554, p=.001$; and trust (TR) $\mathrm{r}=.271, \mathrm{p}=.001$; and USA perceived privacy (PRIV) $\mathrm{r}=.377, \mathrm{p}=.001$; perceived risk (SEC) $\mathrm{r}=.552$, $\mathrm{p}=.001$; and trust (TR) $\mathrm{r}=.457, \mathrm{p}=.001$. The strength of the correlations shows that respondents felt more influenced by perceived Web security than by trust in their attitudes toward and intentions to use Internet banking These correlations support the findings of other researchers who found perceived [Web] security to be a highly significant predictor of intentions to use Internet banking [e.g. 18; 3; 56].

Table 4: Pearson Correlations for Study Variables Saudi Arabia (SA) and United States (USA)

\begin{tabular}{|l|c|c|c|c|c|c|c|c|c|c|}
\hline \multicolumn{7}{|c|}{ Pearson Correlations (SA) } & \multicolumn{5}{c|}{ Pearson Correlations (USA) } \\
\hline & PRIV & SEC & TR & ATT & ITU & PRIV & SEC & TR & ATT & ITU \\
\hline PRIV & 1 & $.626^{* *}$ & $.415^{* *}$ & $.358^{* *}$ & $.400^{* *}$ & 1 & $.504^{* *}$ & $.585^{* *}$ & $.377^{* *}$ & $.433^{* *}$ \\
\hline SEC & & 1 & $.446^{* *}$ & $.554^{* *}$ & $.532^{* *}$ & & 1 & $.870^{* *}$ & $.552^{* *}$ & $.554^{* *}$ \\
\hline TR & & & 1 & $.271^{* *}$ & $.313^{* *}$ & & & 1 & $.457^{* *}$ & $.491^{* *}$ \\
\hline ATT & & & & 1 & $.750^{* *}$ & & & & 1 & $.862^{* *}$ \\
\hline ITU & & & & & 1 & & & & & 1 \\
\hline$* *$ Correlation is significant at the 0.01 level (2-tailed). & & & & \\
\hline
\end{tabular}

\section{Research Questions}

Table 5 shows the group statistics for the means, standard deviations and standard error of the means for the variables related to the five research questions. The means for the SA sample are all above 4 on a scale of 1 to 5 , indicating that SA respondents felt stronger in their choices when considering the variables of the study. This might be expected in a culture deemed more socially strict, and where the history and experience with Internet banking are less [3].

Directly below Table 5, Table 6 shows the results of the independent samples t-tests used for comparing the means for the two samples on the five research questions. The discussion of the analysis of each of the five research questions appears below Tables $\mathrm{Y}$ and $\mathrm{Z}$.

Table 5: Group Statistics for RQ 1-5

\begin{tabular}{|c|c|c|c|c|c|c|}
\hline $\begin{array}{c}\text { Research } \\
\text { Questions }\end{array}$ & Measure & Nation & $\mathrm{N}$ & Mean & $\begin{array}{c}\text { Std. } \\
\text { Deviation }\end{array}$ & $\begin{array}{c}\text { Std. Error } \\
\text { Mean }\end{array}$ \\
\hline \multirow{2}{*}{ RQ-1 } & \multirow{2}{*}{ Security } & SA & 173 & 4.2789 & .69771 & .05305 \\
\cline { 3 - 7 } & & USA & 125 & 3.8900 & .77081 & .06894 \\
\hline \multirow{2}{*}{ RQ-2 } & \multirow{2}{*}{ Privacy } & SA & 173 & 4.200385 & .7614245 & .0578900 \\
\cline { 3 - 7 } & & USA & 125 & 3.408240 & .9427200 & .0843194 \\
\hline \multirow{2}{*}{ RQ-3 } & \multirow{2}{*}{ Trust } & SA & 173 & $4.083237 \mathrm{E} 0$ & .7061251 & .0536857 \\
\cline { 3 - 7 } & & USA & 125 & $3.777600 \mathrm{E} 0$ & .9762390 & .0873175 \\
\hline \multirow{2}{*}{ RQ-4 } & \multirow{2}{*}{ Attitude } & SA & 173 & $4.35773 \mathrm{E} 0$ & .5619226 & .0427222 \\
\cline { 3 - 7 } & & USA & 125 & $3.94560 \mathrm{E} 0$ & .7148442 & .0639376 \\
\hline \multirow{2}{*}{ RQ-5 } & \multirow{2}{*}{ Intention/Use } & SA & 173 & $4.344894 \mathrm{E} 0$ & .6752318 & .0513369 \\
\cline { 3 - 7 } & & USA & 125 & $4.120160 \mathrm{E} 0$ & .9258736 & .0828127 \\
\hline
\end{tabular}


Table 6: Independent Samples t-Tests

\begin{tabular}{|c|c|c|c|c|c|c|c|c|c|c|}
\hline & & \multicolumn{2}{|c|}{ Levene's Test } & \multicolumn{7}{|c|}{ t-test for Equality of Means } \\
\hline & & \multirow[b]{2}{*}{$\mathrm{F}$} & \multirow[b]{2}{*}{ Sig. } & \multirow[b]{2}{*}{$\mathrm{t}$} & \multirow[b]{2}{*}{$\mathrm{df}$} & \multirow{2}{*}{$\begin{array}{l}\text { Sig. } \\
(2- \\
\text { tailed })\end{array}$} & \multirow{2}{*}{$\begin{array}{c}\text { Mean } \\
\text { Difference }\end{array}$} & \multirow{2}{*}{$\begin{array}{l}\text { Std. Error } \\
\text { Difference }\end{array}$} & \multicolumn{2}{|c|}{$\begin{array}{l}95 \% \text { Confidence } \\
\text { Interval of the } \\
\text { Difference }\end{array}$} \\
\hline & & & & & & & & & Lower & Upper \\
\hline $\begin{array}{c}\text { RQ1 } \\
\text { Security }\end{array}$ & $\begin{array}{c}\text { Equal variances } \\
\text { assumed }\end{array}$ & 1.618 & .204 & 4.54 & 296 & .000 & .38890 & .08560 & .22043 & .55737 \\
\hline $\begin{array}{c}\text { RQ2 } \\
\text { Privacy }\end{array}$ & $\begin{array}{l}\text { Equal variances } \\
\text { not assumed }\end{array}$ & & & 7.75 & 231 & .000 & .7921454 & .1022792 & .5906279 & .9936628 \\
\hline $\begin{array}{l}\text { RQ3 } \\
\text { Trust }\end{array}$ & $\begin{array}{l}\text { Equal variances } \\
\text { not assumed }\end{array}$ & & & 2.98 & 213 & .003 & .3056370 & .1025012 & .1035929 & .5076811 \\
\hline $\begin{array}{c}\text { RQ4 } \\
\text { Attitude }\end{array}$ & $\begin{array}{c}\text { Equal variances } \\
\text { not assumed }\end{array}$ & & & 4.89 & 227 & .000 & .3761726 & .0768974 & .2246482 & .5276971 \\
\hline $\begin{array}{c}\text { RQ5 } \\
\text { Intention/Use }\end{array}$ & $\begin{array}{c}\text { Equal variances } \\
\text { assumed }\end{array}$ & 2.963 & .086 & 2.42 & 296 & .016 & .2247340 & .0927343 & .0422319 & .4072361 \\
\hline
\end{tabular}

Research question 1: There will be a significant difference on the measurement of perceived web security (SEC) between SA and USA respondents.

Research question 1 suggested that SA respondents would value perceived Internet banking security risk differently than their USA counterparts. There was a significant difference in the security scores for SA and USA. An equal variances independent-samples t-test was conducted to compare SA and USA respondents' importance of perceived risk on their intentions to use Internet banking. There was a significant difference in the scores for $S A(M=4.3, S D=.69)$ and USA (M=3.9, $S D=0.77)$ conditions; $t(296)=4.54, p=0.001, \alpha=.05$. These results suggest that nationality can affect respondents 'concerns for security with respect to Internet banking. Specifically, the results suggest that SA respondents have greater concerns about Internet banking security than their USA counterparts. Research question 1 is supported and is in keeping with the findings of other researchers (e.g. 37; 39; 57).

Research question 2: There will be a significant difference with how respondents from SA and USA value privacy (PRIV) of Internet banking information and transactions.

Research question 2 suggested that SA respondents would value their privacy and have greater concern with respect to their Internet banking information and transactions. An independentsamples t-test (equal variances not assumed) was conducted to compare SA and USA respondents' scores with respect to perceived privacy in Internet banking. There was a significant difference in the scores for $S A(M=4.2, S D=.76)$ and USA $(M=3.4, S D=0.94)$ conditions; $\mathrm{t}(231)=7.75, \mathrm{p}=0.001, \alpha=.05$. These results suggest that nationality may affect respondents' importance on level of perceived privacy with Internet banking information and transactions. Specifically, the results suggest that SA respondents showed a higher concern for privacy with respect to their Internet banking information and transactions than their USA counterparts. Research question 2 is supported.

Research question 3: The will be a significant difference on the measurement of trust (TR) concerning Internet banking between SA and USA respondents.

Research question 3 suggested that SA respondents would have a greater interest in the level of trust associated with Internet banking. An independent-samples t-test (equal variances not assumed) was conducted to compare SA and USA respondents' scores with respect to interest 
in Internet banking trust. There was a significant difference in the scores for SA $(M=4.08$, $\mathrm{SD}=.71)$ and USA (M=3.78, $\mathrm{SD}=.98)$ conditions; $\mathrm{t}(214)=2.98, \mathrm{p}=0.003, \alpha=.05$. These results suggest that nationality can affect respondents' interest level in trust for Internet banking. Specifically, study results suggest that SA respondents show a higher concern about trust in Internet banking than their USA counterparts. Research question 3 is supported.

Research question 4: There will be a significant difference on how SA and USA respondents respond to attitude (ATT) toward adoption of Internet banking.

An independent-samples t-test (equal variances not assumed) revealed a statistically reliable difference between the mean number representing Saudi Arabians' attitudes toward adoption of Internet banking over USA respondents ( $\mathrm{M}=4.36, \mathrm{SD}=.56)$ and USA $(\mathrm{M}=3.95, \mathrm{SD}=.72), \mathrm{t}$ $(227)=4.89, p=.001, \alpha=.05$. Research question 4 is supported. The positive findings from RQ3 and RQ4 were supported by earlier researchers who found Trust to be a highly significant predictor of customers' adoption of and satisfaction with Internet banking services, (e.g. 21-22; $7 ; 42 ; 41 ; 43-44]$.

Research question 5: Suggested that the element of convenience afforded to all users of IB services would mean that there would not be a significant difference between SA and USA respondents on the measurement intentions (ITU) to use Internet banking.

An equal variances independent-samples t-test was conducted to compare SA and USA respondents' intentions to use Internet banking. There was a significant difference in the scores for $\mathrm{SA}(\mathrm{M}=4.35, \mathrm{SD}=.68)$ and USA $(\mathrm{M}=4.12, \mathrm{SD}=0.93)$ conditions; $\mathrm{t}(296)=2.42, \mathrm{p}=.016$, $\alpha=.05$. These results suggest that nationality can affect respondents' intentions to use Internet banking. Specifically, the findings suggest that SA respondents show a slightly greater propensity toward Internet banking than their USA counterparts. Research question 5 is not supported. The findings here may reflect the relative maturation differences between the two markets - the newer, less extensive Saudi market compared with the older more developed USA market where users with interest in Internet banking may already be saturated.

\section{Limitations and Future Research}

\section{FUTURE RESEARCH AND CONCLUSIONS}

As with any primary research, especially studies involving cross-cultural samples, some limitations are unavoidable. These often present risks that need to be taken into account to further the findings in the chosen field. For example, generalizability in the present study was compromised by the use of different collection methods in different countries and the way in which samples were selected. Some evidence of this lies in that the profiles of the samples were significantly different. Standardising the data collection approaches and use of wider samples would have been prohibitive and costly, but probably would not have affected the present results.

This study explored the relationships and interactions of several groups of respondents to Internet banking variables that are germane to understanding consumers' attitudes toward and their intentions to adopt and use IB. Associations were reveled among several variables basically showing that as perceived risk decreases adoption and use of Internet banking increases. However, causal relationships were not explored. It is recommended that further studies examine the causal relationships through structural models and experimental designs. Future researchers may want to focus and document specific relationships between the adoption and usage of Internet banking services. 


\section{CONCLUSIONS}

The state of Internet banking from making on-line purchases to conducting ordinary banking business matters will continue to become a valued service for banking patrons around the world. The present study explored some relationships between Saudi Arabian and US banking customers and their attitudes toward Internet banking services. Five research questions were presented, analyzed, and the findings discussed. In summary, with respect to RQ1 - Security and RQ2 - Privacy, Saudi Arabian banking customers showed positive significant differences on these constructs over their USA counterparts. These finding suggest that Saudis tend to be more concerned about Internet banking security and privacy of their accounts and records by provider banking institutions. In terms of the importance of Trust and Attitude toward the Adoption of Internet banking services, Saudi banking customers demonstrated positive significant differences compared with respondents from the USA. RQ3 Trust and RQ4 Attitude toward Adoption of Internet banking are related constructs, as Trust was found to be a moderate predictor of customers' adopting and finding satisfaction with Internet banking services. The take away here may be that Saudi banks that employ practices aimed at decreasing security and privacy concerns while increasing customer trust could see greater adoption of their IB services. This may also lead to increases in customer satisfaction and loyalty, and create positive banking relationships. RQ5 suggested because of the convenience observed through using on-line banking services and the fact that, worldwide, convenience tends to be a universally desirable attribute that there would be no significant difference between Saudi Arabian and US respondents in terms of intentions toward adopting and using Internet banking. However, here again Saudis expressed a positive significant difference over their US counterparts. These positive significant findings imply that while the Saudi Arabian economy and its level of development may lag that of the USA, that Saudis who perceive lower security and privacy risks and develop trust in their banking institutions will embrace the use of Internet technology when it comes to selecting banking services.

\section{ACKNOWLEDGEMENT}

This project was funded by the Deanship of Scientific Research (DSR), King Abdulaziz University, Jeddah, under grant no. 429/003-17. The author, therefore, acknowledge with thanks DSR technical and financial support.

\section{References}

1. Lichtenstein, S. and Williamson, K. (2006). Understanding consumer adoption of Internet banking: an interpretive study in the Australian banking context. Journal of Electronic Commerce Research, 7 (2), 50 66

2. Redlinghuis, A. \& Rensleigh, C. (2010). Customer perceptions on Internet banking information protection. Journal of Information Management, 12 (1), 43-57

3. Nasri, W. (2011). Factors influencing the adoption of Internet banking in Tunisia. International Journal of Business and Management, 6 (8), 143-160

4. Rizk, M. (2014). Organizational \& customer factors influencing adoption of electronic banking: Proposed strategies for Egyptian banking sector. Social Science Research Network, http://ssrn.com/abstract=2483961 or http://dx.doi.org/10.2139/ssrn.2483961

5. Unyathanakorn, K. \& Rompho, N. (2014). Factors affecting customer satisfaction in online banking service. Journal of Marketing Development and Competitiveness, 8 (2), 50-60

6. Dapp, T.F., Stobbe, A. \& Wruuck, P. (2012). The future of mobile payments: New (online) players competing with banks. Current Issues in Global Financial Markets. DB Research, December,http://www.dbresearch.com/PROD/DBR_INTERNET_ /The+future+of+\%28mobile\%29+payments\%3A+New+\%28online\%29+play.pdf 
7. Park, C.H. \& Kim, Y.G. (2003). Identifying key factors affecting consumer purchase behavior in an online shopping context. International Journal of Retail and Distribution Management, 31(1), 16-29

8. Jøsang, A., AlFayyadh, B., Grandison, T., AlZomai, M., \& McNamara, J. (2007). Security usability principles for vulnerability analysis and risk assessment. Proceedings of the Annual Computer Security Applications Conference (ACSAC'07) Miami Beach, 15-24

9. Yoon, H. \& Occena, L. (2014). Impact of customers' perceptions on Internet banking use with a smart phone. Journal of Computer Information Systems, 54 (3), 1-9

10. Glazer, E. \& Yadron, D. (2014). J.P. Morgan Says About 76 Million Households Affected By Cyber Breach. Wall Street Journal, updated, Oct. 2.

11. Ezzi, S. (2014). A theoretical model for Internet banking: Beyond perceived usefulness and ease of use. Archives of Business Research, 2 (2), 31-46

12. DOI: $10.14738 / a b r .22 .184$

13. Sullivan, R. \& Wang, Z. (2005). Internet banking: An exploration in technology diffusion and impact. Working Paper, Research Department, Federal Reserve Bank of Kansas City, 23-45

14. Yulihasri, I. M., \& Daud, K. (2011). Factors that influence customers' buying intention on shopping online. International Journal of Marketing Studies, 3 (1), 128-139

15. Ayadi, A. (2006). Technological and organizational preconditions to Internet Banking implementation: Case of a Tunisian bank. Journal of Internet Banking and Commerce, 11 (1), 67-78

16. Abu-Shanab, E. \& Pearson, M. (2009). Internet banking in Jordan: An Arabic instrument validation process. The International Arab Journal of Information Technology, 6 (3), 235-246

17. Al-Somali, S., Gholami, R. \& Clegg, B. (2009). An investigation into the acceptance of online banking in Saudi Arabia. Technovation, 29, 130-141

18. Hanafizadeh, P., Keating, B., \& Khedmatgozar, H. (2014). A systematic review of Internet banking adoption. Telematics and Informatics, 31, 492-510

19. Safeena, R., Hundewale, N. \& Kamani, A. (2011). Customer's adoption of mobile-commerce: A study on emerging economy. International Journal of e-Education, e-Business, e-Management and e-Learning, 1, (3), 228-233

20. Al-Jabri, I.M. \& Sohail, M.S. (2012). Mobile Banking Adoption: Application of Diffusion of Innovation Theory. Journal of Electronic Commerce Research, 13 (9), 379-391

21. Khurshid, A., Rizwan, M. \& Tasneem, E. (2014). Factors contributing towards adoption of E-banking in Pakistan. International Journal of Accounting and Financial Reporting, 4 (2), 437- 455

22. Szymanski, David M. \& Richard T. Hise (2000). E-satisfaction: An initial examination. Journal of Retailing, $76(3), 309-322$

23. Wagner, J. \& Rydstrom, G. (2001). Satisfaction, trust and commitment in consumers relationships with online retailers. E - European Advances in Consumer Research, 5, eds. Andrea Groeppel-Klien and FrankRudolf Esch, Provo, UT: Association for Consumer Research, 276-281

24. Eid, M.I. (2011). Determinants of e-commerce customer satisfaction, trust, and loyalty in Saudi Arabia. Journal of Electronic Commerce Research, 12 (1), 79-91

25. Yousafzai, S., Pallister, J., \& Foxall, G. (2003). A proposed model of e-trust for electronic banking. Technovation, 23, 847-860

26. Farrell, V., Scheepers, R. \& Joyce, P. (2003). Models of trust in business-to-consumer electronic commerce. in K.V. Andersen, S. Elliot, P. Swatman, E. Trauth and N. Bjørn-Andersen (Eds.) Seeking Success in Ebusiness: A Multidisciplinary Approach, London: Kluwer Academic Publishers, 51-67.

27. McKnight, D.H., Choudhury, V. \& Kacmar, C. (2002). Developing and validating trust measures for ecommerce: An integrative typology. Information Systems Research, 13 (3), 334-359

28. Pavlou, P.A., (2003). Consumer acceptance of electronic commerce: Integrating trust and risk with the technology acceptance model. International Journal of Electronic Commerce, 7 (3), 101-134 
29. Ochuko, R.E., Cullen, A.J. \& Neagu, D. (2009). Overview of factors for Internet banking adoption. Proceedings in International Conference on Cyberworlds, University of Bradford, United Kingdom, 164170

30. Zanoon, N. \& Gharaibeh, N. (2013). The impact of customer knowledge on the security of e-banking. International Journal of Computer Science and Security (IJCSS), 7 (2), 81-92

31. Zulfikar, R. (2010). Phishing attacks and countermeasures. In Mark Stamp \& Peter Stavroulakis (Eds.), Handbook of Information and Communication Security, Springer Publishing

32. Subsorn, P. \& Limwiriyakul, S. (2012). A comparative analysis of Internet banking security in Thailand: A customer perspective. Procedia Engineering, 32, 260-272, doi:10.1016/j.proeng.2012.01.1266

33. Van der Merwe, A., Loock, M., \& Dabrowski, M. (2005). Characteristics and responsibilities involved in a phishing attack. WISICT '05 Proceedings of the 4th International symposium on Information and communication technologies, 249-254

34. Rousseau D., Sitkin, S., Burt, R., \& Camerer, C. (1998). Not so different after all: a cross discipline view of trust. Academy of Management Review, 23 (3), 393-404

35. McKnight, D.H., \& Chervany, N. (2002). What trust means in e-commerce customer relationships: an interdisciplinary conceptual typology. International Journal of Electronic Commerce, 6 (2), 35-59

36. Pavlou, P.A. \& Gefen, D. (2004). Building effective online marketplaces with institution-based trust. Information Systems Research, 15 (1), 37-59

37. Nor, K.M. \& Pearson, J.M. (2007). The influence of trust on Internet banking acceptance. Journal of Internet Banking and Commerce, 12 (2), 2-10

38. Salisbury, W.D., Pearson, R.A., Pearson, A.W. \& Miller, D.W. (2001). Perceived security and World Wide Web purchase intention. Industrial Management \& Data Systems, 101 (4), 165 - 177 DOI http://dx.doi.org/10.1108/02635570110390071

39. Lee, G. \& Lin, H. (2005). Perceptions of E-service quality in online shopping. International Journal of Retail and Distribution Management, 33 (2), 161-176

40. Cheng, T.C., Lam, D., \& Yeung, A. (2006). Adoption of internet banking: an empirical study in Hong Kong. Decision Support Systems, 42, 1558-1572

41. Khalfan, A., Yaqoub, S.Y. AlRefaei, Y. and Al-Hajery, M. (2006). Factors influencing the adoption of internet banking in Oman: a descriptive case study analysis. International Journal of Financial Services Management. 1 (2), 155-172

42. Flavián, C. \& Guinalíu, M. (2006). Consumer trust, perceived security and privacy policy: three basic elements of loyalty to a web site. Industrial Management \& Data Systems, 106 (5), 601-620

43. Evanschitzky, H., Gopalkrishnan R.I., Hessea, J. \& Ahlert, D. (2004). E-satisfaction: a re-examination. Journal of Retailing 80 (2), 239-247

44. Cyr, D. (2008). Modeling website design across cultures: Relationships to trust, satisfaction and E-loyalty. Journal of Management Information Systems, 24 (4), 47-72

45. Kim, D.J., Donald, L.F. \& Rao, H.R. (2009). Trust and satisfaction, Two stepping stones for successful ecommerce relationships: A longitudinal exploration. Information Systems Research, 20 (2), 237-257

46. Liao, Z., \& Cheung, M.T. (2002). Internet-based e-banking and consumer attitudes: an empirical study. International Journal of Information Management, 19 (1), 63-74.

47. Lee, E.J., Kwon, K.N., \& Schumann, D.W. (2005). Segmenting the non-adopter category in the diffusion of Internet banking. The International Journal of Bank Marketing, 23 (5), 414-437.

48. Ahangar, R.G. (2011). An investigation into the determinant of customers' preferences and satisfaction of internet banking: Empirical study of Iranian banking industry. Journal of Applied Sciences, 11 (3), 426437, DOI: $10.3923 /$ jas. 
49. Lee, M. (2008). Factors influencing the adoption of internet banking: An integration of TAM and TPB with perceived risk and perceived benefit. Electronic Commerce Research and Applications, 1-12, doi:10.1016/j.elerap

50. Lucas, S.R. (2014). Beyond the Existence Proof: Ontological Conditions, Epistemological Implications, and In-Depth Interview Research. Quality \& Quantity, 48, 387-408

51. Scott, M. \& Albaum, G. (2010). An Introduction to Marketing Research, USA: Qualtrics Survey University

52. Aiken, L. S., \& West, S. G. (1991). Multiple regression: Testing and interpreting interactions, Newbury Park: Sage

53. Bagozzi, R. (1992). The self-regulation of attitudes, intentions, and behavior. Social Physiology Quarterly, 55 (2), 178-204

54. McClelland, G.H., \& Judd, C.M. (1993). Statistical difficulties of detecting interactions and moderator effects. Psychological Bulletin, 114 (2), 376-390

55. The World Factbook (2013-14). Washington, DC: Central Intelligence Agency,

56. https://www.cia.gov/library/publications/the-world-factbook/index.html

57. Olatokun, W. \& Owoeye, O. (2012). Influence of individual, organizational and system factors on attitude of online banking users. Proceedings of Informing Science \& IT Education Conference (InSITE), 389-403

58. Safeena, R., Date, D., \& Kamani, A. (2011). Internet banking adoption in an emerging economy: Indian consumer's perspective. International Arab Journal of e-Technology, 2 (1), pp. 56-64

\section{APPENDIX: THE QUESTIONNAIRE}

\begin{tabular}{|c|c|}
\hline Construct items & Source \\
\hline Privacy: & \\
\hline Banks carefully collect the personal information. & Ahangar, 2011 \\
\hline Bank website is completely secure for personal information. & Ahangar, 2011 \\
\hline $\begin{array}{l}\text { You can rely on bank that they don't misuse your personal information. } \\
\text { Web Security: }\end{array}$ & Ahangar, 2011 \\
\hline I would feel secure sending sensitive information across the IB. & Cheng, Lam, and Yeung, 2006 \\
\hline The IB is a secure means through which to send sensitive information. & Cheng, Lam, and Yeung, 2006 \\
\hline $\begin{array}{l}\text { I would feel totally safe providing sensitive information about myself } \\
\text { over the IB. }\end{array}$ & Cheng, Lam, and Yeung, 2006 \\
\hline $\begin{array}{l}\text { Overall, the IB is a safe place to transmit sensitive information. } \\
\text { Trust: }\end{array}$ & Cheng, Lam, and Yeung, 2006 \\
\hline I trust my bank; therefore I trust its online banking service. & Al-Somali, Gholami, and Clegg, 2009 \\
\hline The online banking site keeps its promises and commitments. & Al-Somali, Gholami, and Clegg, 2009 \\
\hline $\begin{array}{l}\text { I trust my bank's online banking site. } \\
\text { Attitude: }\end{array}$ & Al-Somali, Gholami, and Clegg, 2009 \\
\hline I will encourage the use of online banking among my colleagues. & Al-Somali, Gholami, and Clegg, 2009 \\
\hline $\begin{array}{l}\text { I am not satisfied with using traditional banking services when carrying } \\
\text { out financial activities. }\end{array}$ & Al-Somali, Gholami, and Clegg, 2009 \\
\hline Overall, the attitude towards online banking usage is positive. & Al-Somali, Gholami, and Clegg, 2009 \\
\hline I think that using online banking is a good idea. & Lee, 2008 \\
\hline $\begin{array}{l}\text { I think that using online banking for financial transactions would be a } \\
\text { wise idea. }\end{array}$ & Lee, 2008 \\
\hline $\begin{array}{l}\text { I think that using online banking is pleasant In my opinion; it is } \\
\text { desirable to use online banking. } \\
\text { Intention to Use: }\end{array}$ & Lee, 2008 \\
\hline I will use online banking on regular basis in the future. & Al-Somali, Gholami, and Clegg, 2009 \\
\hline $\begin{array}{l}\text { I expect my use of online banking for handling my financial transactions } \\
\text { to continue in the future. }\end{array}$ & Al-Somali, Gholami, and Clegg, 2009 \\
\hline I will strongly recommend others to use online banking. & Al-Somali, Gholami, and Clegg, 2009 \\
\hline
\end{tabular}

